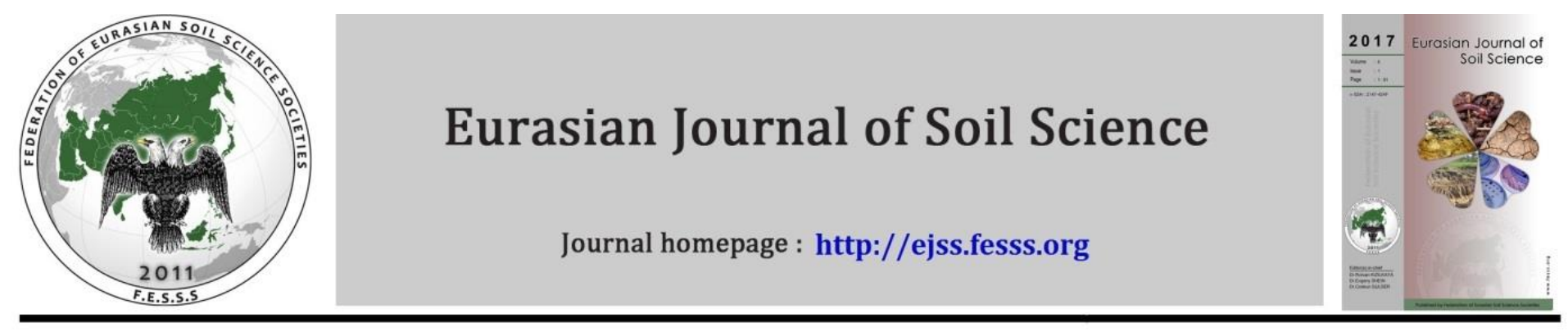

\title{
Determination of engineering properties of soil on railway track routes (An example of Turkey between the cities of Sivas and Erzincan) Sevda Gören *, Kenan Gelisli
}

Karadeniz Technical University, Faculty of Engineering, Department of Geophysical Engineering, Trabzon, Turkey

\section{Article Info}

Received : 02.02.2017 Accepted : 11.05.2017

\begin{abstract}
Subsurface structure and engineering properties of the Sivas and Erzincan railway route were investigated by using velocities of seismic wave, electrical resistivity, standard penetration test (SPT) data and laboratory results, which were collected from survey sites referred to in this study. For this reason, 62 seismic refraction and vertical electrical resistivity (VES) measurements at 59 points were done along the survey route. Moreover, 11 mechanical boreholes with SPT were drilled. Laboratory tests were applied on soil samples taken from boreholes for geotechnical features. Longitudinal, shear wave velocities and elastic parameters were determined by seismic refraction method, and underground resistivity distribution was calculated by VES and geotechnical data and SPT results were evulated for the subsurface integrity. Engineering properties of a $6.8 \mathrm{~km}$ stretch of planned railway alignment in southeastern Sivas were calculated in this study. According to these results, unsuitable segments of the high-speed alignment which have low groundwater level and low bearing capasities which depend on dynamic properties were examined.
\end{abstract}

Keywords: High speed railway track, railway alignment, geophysical methods, SPT test, soil engineering parameters.

(C) 2017 Federation of Eurasian Soil Science Societies. All rights reserved

\section{Introduction}

One of the most efficient transportation network is high speed railway which is depend on technical, economical and environmental issues. When a railway line has to be built between two points, there are several possible routes. First of all, experts have to determine a suitable alignment. Areas of high bearing capacity and hard soils are regarded as geological properties suitable for railway tracks. Factors which influence planning of railway track routes are geological structure, topography, landslides regions, bearing capasity of soil and groundwater level. Track route investigations can be done by using geophysical, geological and geotechnical methods.

Geophysical methods have been used for many years by engineers in soils and foundation applications (Telford et al., 1990; Sharma, 1997). Geophysics has proved quite relevant in highway site investigations since recently (Moore 1952; Nelson and Haigh 1990; Lippincott et al., 2000). Seismic not only provides means for probing the properties of soils, sediments and rock outcrops but are also used to calculate dynamic properties of soils including the soil's compression and shear wave velocities. These properties are key parameters in predicting the response of soils and soil-structure systems to dynamic loading. Geophysical methods like electrical resistivity have been used in mapping subsurface geologic sequence and

\footnotetext{
${ }^{*}$ Corresponding author.

Karadeniz Technical University, Faculty of Engineering, Department of Geophysical Engineering, 61080 Trabzon, Turkey

Tel.: +904623772030

e-ISSN: 2147-4249

E-mail address: sgoren@ktu.edu.tr DOI: $10.18393 /$ ejss.314701
} 
concealed geological structures (Olorunfemi et al., 2004; Adiat et al., 2009). The main aim of resistivity surveys is to delineate vertical and horizontal underground structures with electrical contrasts.

Geotechnical properties of soils have been identified by laboratory tests and in situ measurements (Bowless, 1988; Kulhawy and Mayne, 1990; Das, 2009). Investigations of bearing capacity of soil was started with Prandtl's work which includes plastic equilibrium theory (Prandtl, 1921). After this work, several fundamental research papers were written about this topic (Terzaghi, 1943; Terzaghi and Peck, 1948; Meyerhof, 1956, 1965). Equation of bearing capacity which was offered by Meyerhof is safety zone and Bowless was improved a new bearing capasity formulae which Meyerhof's equation need to increase about percent of fifty depend on SPT (N) values (Bowless, 1996). Schulze indicated that using the seismic wave velocity technique is more realistic than using boreholes data which have soil samples and geotechnical methods which include laboratory results (Schulze, 1943). Imai and Yoshimura (1976), Tahtam (1982), Wilkens et al. (1984), Phillips et al. (1989), Keçeli (1990), Jongmans (1992), Sully and Campanella (1995), Pyrak-Nolte et al. (1996), Uyanık (1999), Kurtuluş (2000), Turker (2004), Tezcan et al. (2006), Ulugergerli and Uyanık (2007), Uyanık and Turker (2007), Uyanık and Ulugergerli (2008) and Tezcan et al. (2009) worked about bearing capacity of soil formulae according to longitudinal wave velocity $\left(V_{p}\right)$, shear wave velocity $\left(\mathrm{V}_{\mathrm{s}}\right)$ and features of foundation.

The study includes the most important part of railway network which is between the cities of Sivas and Erzincan in Turkey. A $6.8 \mathrm{~km}$ stretch of railway track was investigated for engineering properties of soil. Before railway track route construction, geophysical and geological, boreholes and laboratory tests surveys were done. In terms of suitability, railway track is analysed by using data which are gained from geological and geotechnical surveys and dynamic results which are calculated in-situ.

\section{Material and Methods}

\section{Geology of survey site}

The study area is away from $15 \mathrm{~km}$ the city centre of Sivas which is located within Sivas Basin characterised which includes different kinds of formations (Figure 1a). This basin is spreaded in northeastern and southwestern direction in the middle of Sivas city. Its length and width are about $250 \mathrm{~km}$ and $50 \mathrm{~km}$, respectively. The railway track sits on formations of Quaternary allivium and pliocene conglomera, sandstone and siltstone. Sivas Basin's stratigraphy includes Pazarclk Volcanites (Paleocene), Gülandere Formation (Eocene), Selimiye Formation (Oliocene), Kemah Formation (Alt Miocene), Hafik Formation (Lower - Middle Miosene), İncesu Formation (Upper Miocene - Lower Pliocene), Bayat Volcanites (Upper Pliocene), Travertines and Allivium (Quaterner) (Ayaz and Atalay, 2006) (Figure 1b).

Gülandere and Kemah Formations, Selimiye and Hafik Formations are settled down shallow seabed, transition zones, sabkha, inta-continental zones and transient lakes. İncesu Formation is also deposited in rivers and lacustrine lakes zones. Pazarcık volcanites which contain basalt, andesite and tuff are located southwest of the basin, between Yıldizeli and Akmağdeni, outcropped around Refahiye. Angular uncomformity can be seen on fundamental rocks.

\section{Methods}

The velocity of sound travelling through the sub-surface varies with material composition and compaction. Seismic energy transmitted from a source at the surface will undergo refraction at boundaries between different media and eventually return to the surface. Seismic refraction surveying makes use of this phenomenon to determine ground structure by observing the time taken for energy to travel through the subsurface. The SeisImager software is generally used in near surface surveys of the seismic refraction method (Sheehan et al., 2005). The seismic refraction time-term inversion method found in this programme is a quick data analysis approach which will accurately provide information such as depth to bedrock as long as the seismic velocity of site increases with depth.

A commercially available 12-channel seismic system was used to record seismic arrivals in this study. The system consisted of 12 vertical $14 \mathrm{~Hz}$ geophones and 12 horizontal $4.5 \mathrm{~Hz}$ geophones connected to a Geometrics seismograph, which in turn was linked to a laptop computer. After recording of seismic data, first step is to pick the first arrival times for this method. The first arrival picking was done with the aid of the SeisImager Pickwin 4.2 software in our study. After this section, you have to draw the time-distance graphs which to assign 2 or 3 layers for using time-inversion method. The SeisImager Plotrefa 2.9 software was used to estimate depth of layers and velocities by time-term inversion method. 


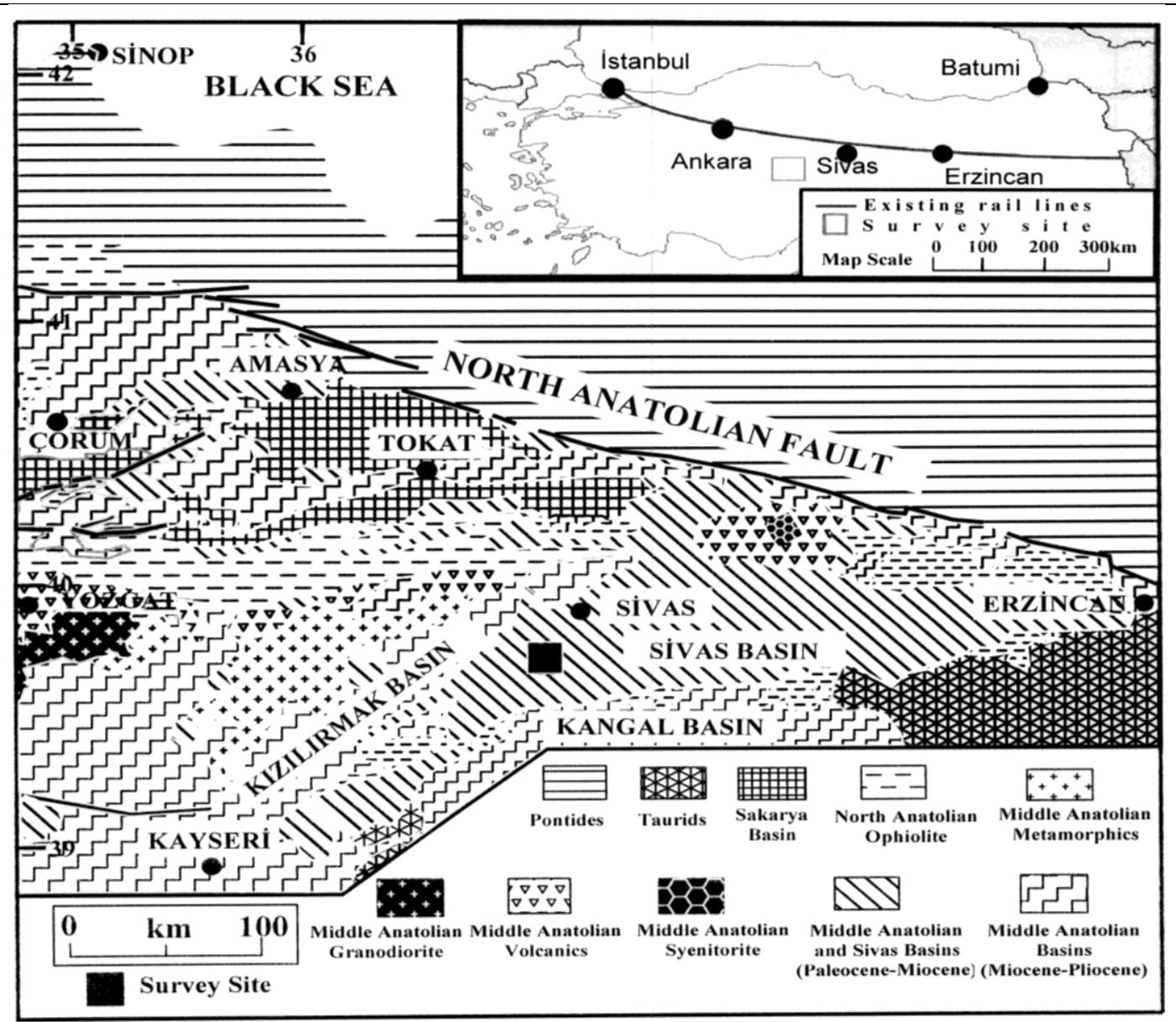

Figure 1a. Location and general geology map of survey site

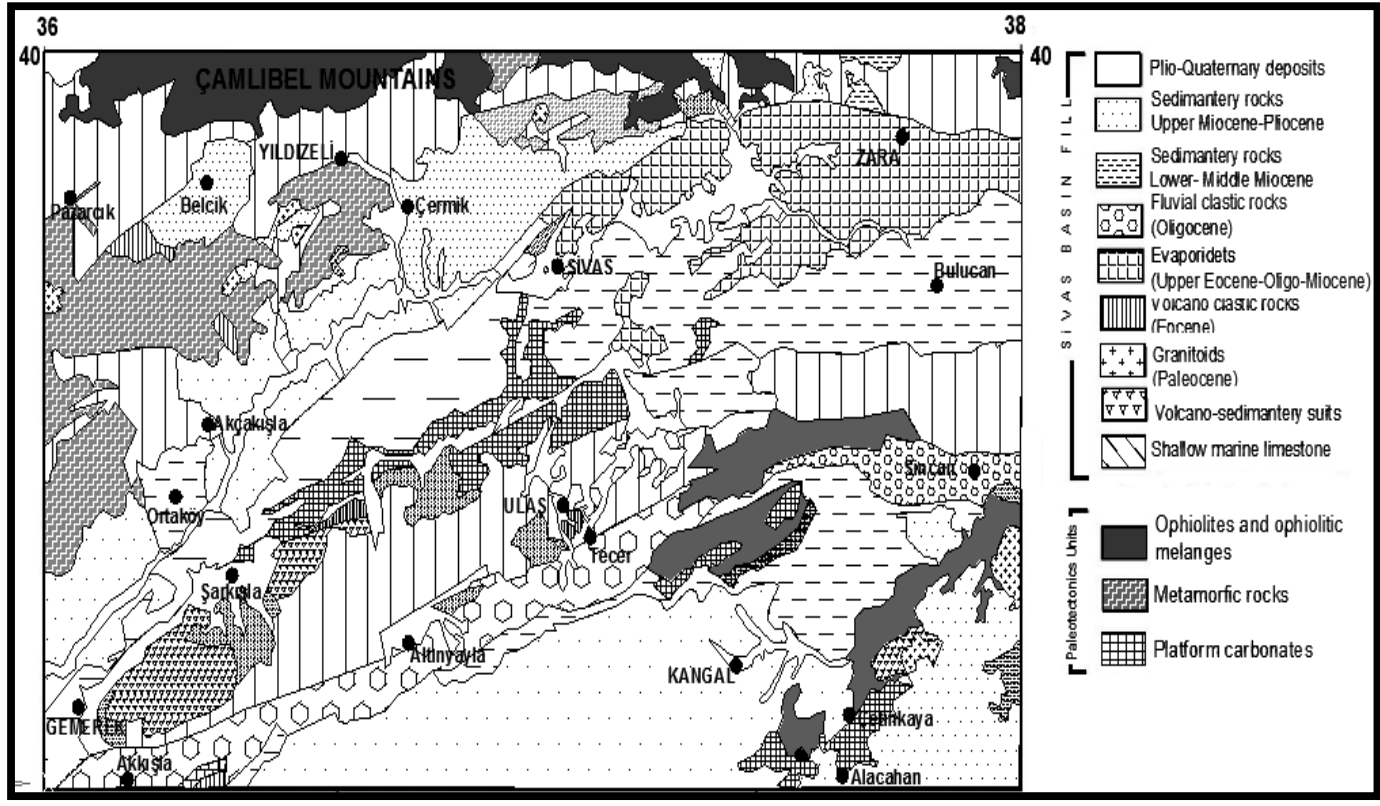

Figure 1b. Local geology map of survey site (Sivas Basin)

After estimating depth of layers and velocities, you can calculate elastic parameters for determining engineering properties. The mechanical properties associated with dynamic loading are shear wave velocity, Shear Modules, Young Modules, Bulk Modules and Poisson Ratio. Elastic parameters were calculated from shear wave and compressional wave velocities measured using seismic refraction method. Poisson ratio is a fundamental parameter is difficult to measure and it is usually estimated in engineering calculations. A suggested range of values changes 0.00-0.5. Young modules is a measure of the stiffness of an elastic material and is a quantity used to characterize materials. Bulk modulus is defined as the ratio of the 
infinitesimal pressure increase to the resulting relative decrease of the volume. We used the formulas of elastic parameters mentioned below (Table 1).

Table 1. Formulas for dynamic-elastic parameters

\begin{tabular}{lll}
\hline Parameters & Formulas & Units \\
\hline Density & $\rho=0.31 V_{p}^{0.25}$ & $\mathrm{gr} / \mathrm{cm}^{3}$ \\
Shear Modulus & $G=\frac{1}{100} \rho V_{s}^{2}$ & $\mathrm{~kg} / \mathrm{cm}^{2}$ \\
Poisson Ratio & $v=\frac{V_{p}^{2}-2 V_{s}^{2}}{2\left(V_{p}^{2}-V_{s}^{2}\right)}$ & - \\
Young Modulus & $E=G \frac{3 V_{p}^{2}-4 V_{s}^{2}}{V_{p}^{2}-V_{s}^{2}}$ & $\mathrm{kPa}$ \\
Bulk Modulus & $K=\rho\left(V_{p}^{2}-\frac{4}{3} V_{s}^{2}\right)$ & $\mathrm{kPa}$ \\
\hline
\end{tabular}

Electrical resistivity surveys create an electrical current in the ground using two dedicated electrodes, and measure the resulting electrical potential field using a further electrodes. Vertical electrical sounding (VES) is a geophysical method for investigation of a geological medium. The method is based on the estimation of the electrical conductivity or resistivity of the medium. The estimation is performed based on the measurement of voltage of electrical field induced by the distant grounded electrodes (current electrodes). The recorded values were calculated to determine apparent resistivity of soil, $\rho$ a ( $\Omega \mathrm{m}$ ) using equation.

$$
\rho_{a}(\Omega m)=k \frac{\Delta V}{I}
$$

$\mathrm{K}$ : geometric factor, I: measured voltage and $\Delta V$ :observed potential difference can be defined.

Electrical resistivity method utilized Vertical Electrical Sounding in the survey site. The VES entatiled 1-D vertical probing of the surface. Electrical resistivity imaging system, ABEM SAS 4000, were used in present study. Calculated apparent resistivity were interpreted quantitatively by partial curve matching and computer iteration technique using IPES6 (Başokur, 1999) software.

Bearing capacities along tracks were calculated by the using seismic method (Imai and Yoshimira, 1976; Tezcan, 2006; Keçeli, 2010), depending on triaxial compression test, cohesion and angle of internal friction which were found from laboratory tests (Terzaghi, 1943; Broms, 1964) and SPT (N) values (Terzaghi and Peck, 1948; Meyerhof, 1956; Meyerhof, 1974).

Based on Terzaghi's bearing capacity theory, column load (P) is resisted by shear stresses at edges of three zones under the footing and the overburden pressure, $q(=\gamma \mathrm{D})$ above the footing. The first part in the equation is related to the cohesion of the soil. The second part is related to the depth of the footing and overburden pressure.

The third part is related to the width of the footing and the length of the shear stress area. Equation 1 was used for Terzaghi's bearing capasity calculations. $K_{1}, k_{2}$ : coefficients of foundation shape, $c$ : cohesion, $B$ : width of footing, $\gamma$ : unit weight of soil can be determined. The bearing capacity factors, $N c, N q, N \gamma$, are functions of internal friction angle.

$$
q_{u}=k_{1} c N_{c}+P_{0}^{\prime} N_{q}+k_{2} \gamma B N_{\gamma}
$$

The Broms approach to computing bearing capacity is equation 3. When the rail-tie system is considered as a contiguous unit placed on the ballast and subgrade, the Broms approach provides a reasonable estimate of the general bearing capacity failures that occur under field conditions. The Equation 3 for bearing capacity equation as total cohesion $(c)$, subballast material $(\gamma)$, width of footing $(B)$, surcharge loading $\left(q_{0}\right)$ is defined as 


$$
q_{u}=c N_{c}+q_{0} N_{q}+0.5 \gamma B N_{\gamma}
$$

Terzaghi and Peck $(1948,1967)$ method is for settlement of $25 \mathrm{~mm}$. It relates blow counts $\left(N^{\prime}\right)$, width of footing $(B)$ and groundwater level $\left(C_{w}\right)$. The equation for bearing capacity equation is as (equation 4 );

$$
q_{u l t}=11 x N^{\prime} x C_{w}
$$

According to the Terzaghi approach, Meyerhof has improved the ultimate bearing capacity $q_{\text {net (all })=} q_{\text {all }}-\left(\gamma D_{f}\right)$ ) for $25 \mathrm{~mm}$ settlement. Bearing capacity formula was renewed using $\mathrm{N}_{70}$ in 1974 (Meyerhof, 1974).

Imai and Yoshimura (1976) method is based on the relationship between longitudinal seismic wave velocity $\left(V_{p}\right)$ and bearing capacity $\left(q_{u}\right)$. Their bearing capacity formula is given in equation 5 .

$$
q_{u}=10 V_{p}^{3}
$$

Tezcan (2006) which includes calculation of bearing capacity theory will be explained as follows. In order to set a practical upper ceiling for allowable bearing capacity, $\mathrm{q}_{\mathrm{u}}$ which includes rock formations the empirical expression (equation 6) is adjusted to yield gradually reduced values through a factor $S_{v}$, for shear wave velocities $\left(\mathrm{V}_{\mathrm{s}}\right)$, greater than $500 \mathrm{~m} / \mathrm{s}$ and unit weight of soil $(\gamma)$ as follows :

$$
\begin{gathered}
q_{u}=0.024 \gamma V_{s} s_{v} \geq 30.6 \gamma \\
s_{v}=1-3 \times 10^{-6}\left(V_{s}-500\right)^{1.6}
\end{gathered}
$$

Keceli (2010)'s approach is based on the relationship between longitudinal seismic wave velocity $\left(V_{p}\right)$, transverse wave velocity $\left(\mathrm{V}_{\mathrm{s}}\right)$ and bearing capacity. $\rho$ is density. Keceli's formula is given in equation 7 .

$$
q_{u}=\frac{1}{100} * \frac{\rho V_{s}^{2}}{V_{p}}
$$

\section{Results and Discussion}

\section{Applications of geophysical surveys, geological and geotechnical}

Seismic and electrical resistivity methods were used in evaluating the subsurface integrity of a $6.8 \mathrm{~km}$ stretch of railway track in southeastern Sivas basin Boundaries of formations and groundwater levels were searched by using electrical resistivity distribution of subsurface which were found from electical resistivity surveys at 59 points. $\mathrm{Ru}-4$ and $\mathrm{Ru}-5$ of electrical resistivity measurements taken from the Segment-I can be seen in Figure 2.
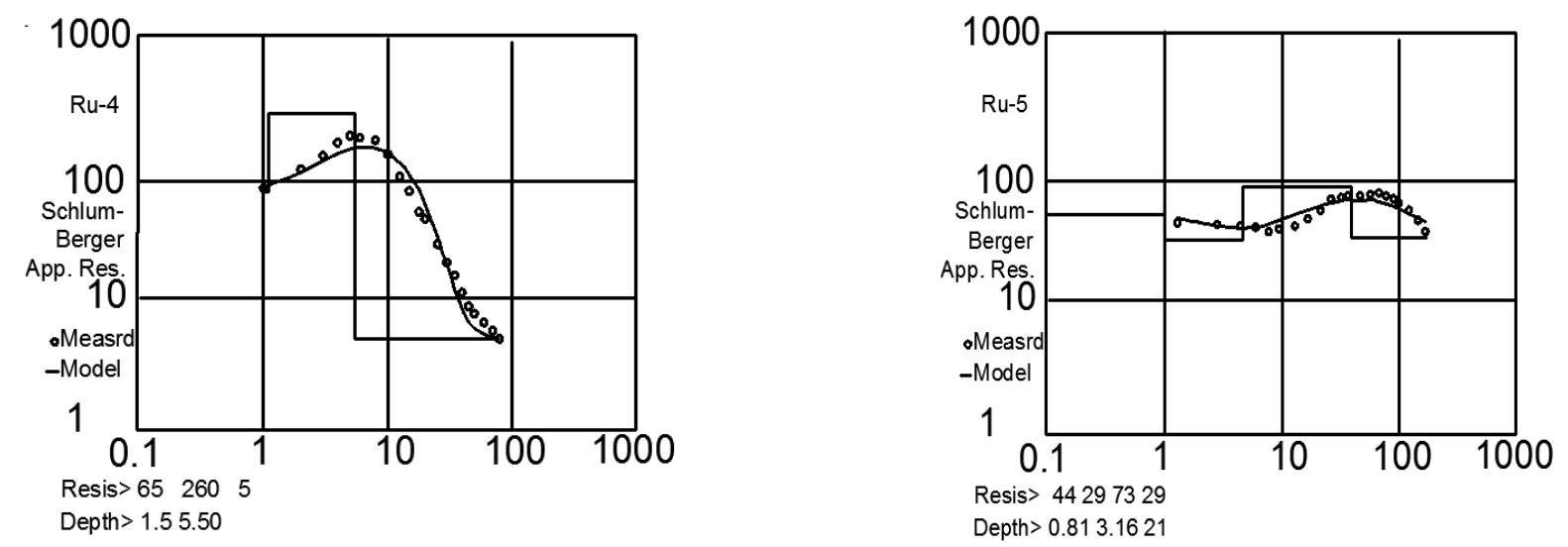

Figure 2. Resistivity sections from examples of electricial measurements (Ru-4 and Ru-5) for Schlumberger array. Yellow circles are defined as measured resistivity values. Red line is for our subsurface resistivity model. After iteration, resistivity values and depths can seen in red colour on the screen. 
Seismic $P$ wave and S wave records were measured at 62 and 56 points, respectively. Elastic parameters and thickness of layers were calculated from calculated seismic velocities whereupon done soil's classifications were derived. After these procedures, the bearing capacities of the soils were analyzed by using seismic wave velocities and geotechnical approaches. Su-4 of seismic refraction measurements taken from the Segment-I were given an example. Seismic record, time-distance graph drawn by first arrivals, calculated subsurface model and velocities were given in Figure 3a,b.

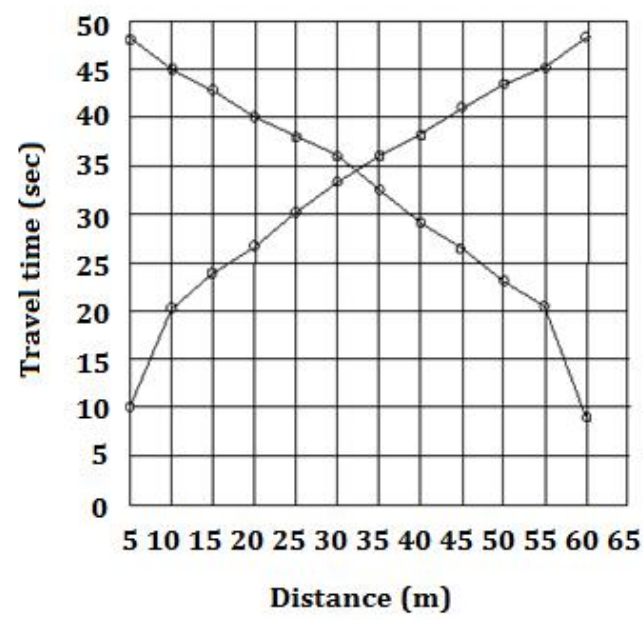

(a)

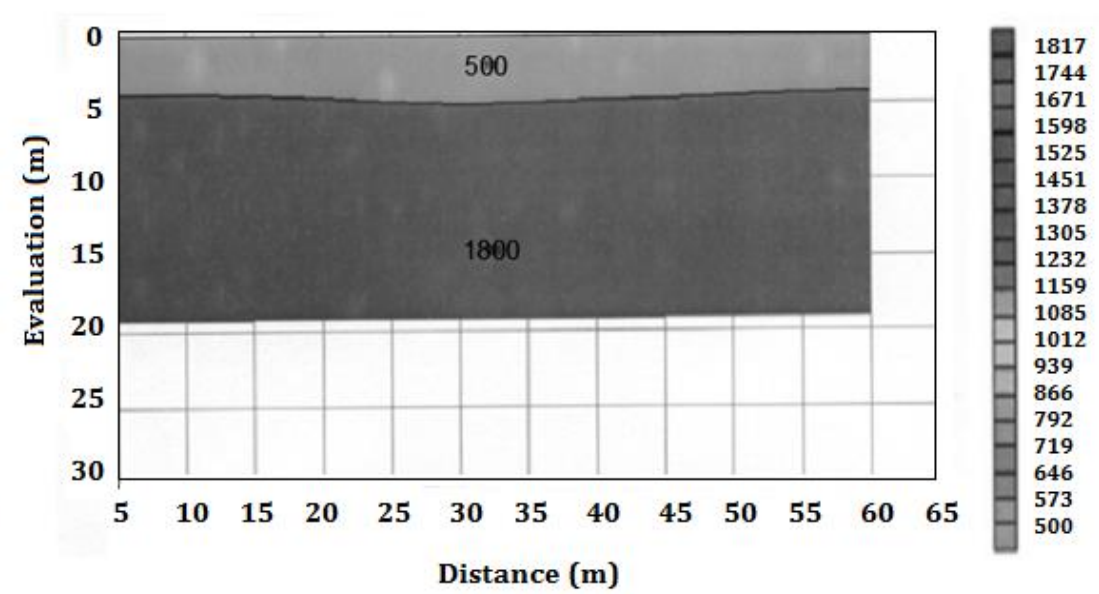

(b)

Figure 3. a) Time (sec) - distance (m) graph b) Subsurface model with time-inversion method

Furthermore, boreholes at 11 points and 3 test pits were drilled to estimate geotechnical properties of soilrock units, soil classification regard as physical engineering parameters, and to investigate groundwater level's. SPT was taken from fundamental boreholes and laboratory tests were done on samples and cores are taken from test pits. 11 boreholes totalling $178.82 \mathrm{~m}$ were drilled on the survey site (see Table 2); their depths vary between 10 and 27 meters. Lithology and groundwater levels of the wells drilled are given in this table.

Table 2. Depth, lithology and groundwater level of study areada drilled boreholes

\begin{tabular}{lclc}
\hline Location & Depth $(\mathrm{m})$ & Lithology & Groundwater Level (m) \\
\hline USK 0+420 & 10.95 & Clayey Gravel Sand & 4.50 \\
KSK 1+068 & 12.31 & Sand & 4.30 \\
ASK 1+915 & 18.45 & Clay - Sand - Gravel & 4.40 \\
ASK 2+580 & 13.55 & Sand & 4.30 \\
YSK 2+900 & 27.00 & Jips - Mudstone - Sandstone & - \\
USK 4+635 & 10.95 & Clay-Sand & 3.00 \\
USK 5+250 & 13.60 & Clay - Sand - Gravel & 6.10 \\
USK 6+305 & 10.10 & Sand - Conglomera & 4.35 \\
SISK 5 & 12.18 & Clay - Sand & 10.00 \\
SISK 8 & 15.20 & Gravel Clay & 10.00 \\
SISK 13 & 16.95 & Clay & 2.40 \\
SISK 14 & 16.95 & Clay - Sand & 2.75 \\
\hline
\end{tabular}

Undisturbed soil samples were taken from 2.5-3.0, 4.0-4.5, 5.5-6.0, 7.0-7.5 and 7.5-8.0 m, respectively. Standard Penetration Tests were done each $1.5 \mathrm{~m}$ and disturbed soil samples were taken. Laboratory tests (According to Atterberg limits, content of water permeability and sieve analysis) were determined on disturbed samples. Undisturbed samples were used for triaxial compressive strength tests. Seven triaxial compressive strength tests were done on samples taken from boreholes on the survey site. Minimum and maximum values of cohesion are $62 \mathrm{KPa}$ and $85 \mathrm{KPa}$. The stiffness of the soil can be determined as Medium Stiff depending on unconfined compressive strength.

$62 \mathrm{P}$ waves and $56 \mathrm{~S}$ waves measurements were recorded with using a 12 channel shallow exploration seismograph. A hammer with a weight of $8 \mathrm{~kg}$ was chosen as a source. Shots were done at the beginning and the end of spread. If the conditions of survey area were avaible, lengths of spread of $60 \mathrm{~m}, 120 \mathrm{~m}$ and spaces of geophones of $5 \mathrm{~m}$ and $10 \mathrm{~m}$, respectively, were selected. 
The distrubition of seismic velocities and subsurface structure was estimated by evaluating seismic records for measured profiles. Collected seismic measurements for six profiles chosen from on the survey site were used for calculating the soil's dynamic density ( $\rho$ ) (Gradner, 1974), Shear Modules (G) (Kramer, 1996), Young Modules (E) (Bowless, 1988) and Poisson Ratio (v). These results are given in Table 3. When the velocities and elastic parameters seen in Table 3 are examined, according to Eurocode- 8 soil classification tables, types of the survey area are classified as from loose to hard soils.

Furthermore, Vertical Electrical Sounding method (VES) was used on the survey site where the the Schlumberger electrode array configuration were utilized at 59 points. The distances between electrodes were set from 1 to $80 \mathrm{~m} \mathrm{(AB/2)}$ and from 0.25 to $10 \mathrm{~m}(\mathrm{MN} / 2)$. VES curves were interpreted quantitatively by partial curve matching and computer iteration technique so that information on the resisvitiy distrubition underground could be obtained.

Table 3. Seismic velocities and dynamic-elastic parameteres for six profiles chosen from survey site randomly

\begin{tabular}{ccccccccc}
\hline $\begin{array}{c}\text { Spread } \\
\text { Name }\end{array}$ & $\begin{array}{c}\text { Layer } \\
\text { Name }\end{array}$ & $\begin{array}{c}\mathrm{Vp} \\
(\mathrm{m} / \mathrm{s})\end{array}$ & $\begin{array}{c}\text { Vs } \\
(\mathrm{m} / \mathrm{s})\end{array}$ & $\begin{array}{c}\rho \\
\left(\mathrm{gr} / \mathrm{cm}^{3}\right)\end{array}$ & $\begin{array}{c}\mathrm{G} \\
\left(\mathrm{kg} / \mathrm{cm}^{2}\right)\end{array}$ & $\begin{array}{c}\mathrm{E} \\
\left(\mathrm{kg} / \mathrm{cm}^{2}\right)\end{array}$ & $\begin{array}{c}\mathrm{K} \\
\mathrm{u}\end{array}$ \\
\hline \multirow{2}{*}{$\mathrm{Su}-10$} & 1 & 408 & 259 & 1.39 & 933 & 2169 & 0.16 & 1071 \\
& 2 & 1649 & 801 & 1.97 & 12655 & 34057 & 0.35 & 36760 \\
Su-20 & 1 & 601 & 285 & 1.53 & 1244 & 3373 & 0.35 & 3876 \\
& 2 & 2242 & 901 & 2.13 & 17290 & 48540 & 0.40 & 84006 \\
Su-30 & 1 & 541 & 262 & 1.49 & 1024 & 2760 & 0.35 & 3002 \\
& 2 & 1656 & 629 & 1.97 & 7812 & 22119 & 0.42 & 43732 \\
Su-40 & 1 & 363 & 159 & 1.35 & 342 & 944 & 0.38 & 1325 \\
& 2 & 1732 & 562 & 2.00 & 6307 & 18178 & 0.44 & 51491 \\
Su-50 & 1 & 413 & 151 & 1.40 & 318 & 905 & 0.42 & 1956 \\
& 2 & 1880 & 712 & 2.04 & 10332 & 29266 & 0.42 & 58259 \\
Su-60 & 1 & 396 & 145 & 1.38 & 290 & 826 & 0.42 & 1778 \\
& 2 & 1732 & 753 & 2.00 & 11322 & 31327 & 0.38 & 44804 \\
\hline
\end{tabular}

The railway tracks were examined in seven segments and Seven underground sections were prepared by using the data obtained from seismic cross-sections, vertical electrical soundings and mechanic drilling studies for clear and easy interpretation.

Segment-I is on the eastern boundary of survey site $(0+000-0+640 \mathrm{~km})$. The length of section is 640 meters. This section obtains five resistivity soundings, four seismic refraction measurements and one mechanical borehole which is called USK-0+420. As a result of the this section which is drawn from collected measurements, it has been found out that the examined track route road has a layered structure. Layers are named according to their depth as Layer 1, Layer 2. The topsoil has resistivity values ranging from 15 to 202 $\Omega \mathrm{m}$ corresponding to clay and sandy gravel respectively; the top soil thickness varies between $0.0 \mathrm{~m}$ and $4.00 \mathrm{~m}$. The topsoil has longitudinal waves values ranging from $410 \mathrm{~m} / \mathrm{sn}$ to $500 \mathrm{~m} / \mathrm{s}$, shear waves values are between $220 \mathrm{~m} / \mathrm{sn}$ and $356 \mathrm{~m} / \mathrm{s}$. Layer 2 is the weathered basement with resistivity and depths values varying between 11-362 $\Omega \mathrm{m}$ and from $4.00 \mathrm{~m}$ to $16.00 \mathrm{~m}$, respectively. Maximum and minimum $\mathrm{P}$ and $\mathrm{S}$ wave velocities range from $1378 \mathrm{~m} / \mathrm{sn}$ to $2370 \mathrm{~m} / \mathrm{s}$ and from $666 \mathrm{~m} / \mathrm{sn}$ to $934 \mathrm{~m} / \mathrm{s}$. Elastisite Modulus are $2038-53056 \mathrm{~kg} / \mathrm{cm}^{2}$ and shear modules are $725-18839 \mathrm{~kg} / \mathrm{cm}^{2}$. According to Eurocode-8 soil classification tables, soil of alignment is B and C which mean very dense sand or gravel or very stiff clay and dense sand or gravel or stiff clay, respectively. Values of Poisson Ratio were calculated between 0.01-0.43. Called USK$0+420$ borehole's lithology is clayey-gravel sand, groundwater level is $4.50 \mathrm{~m}$. According to collected and calculated data, Section-I can be seen in Figure 4a and Figure 4b.The dashed line indicates groundwater level, the continous line shows the boundary of seismic layer. Su_1 is the start point for seismic spread. Ru_1 is one - dimensional resistivity point. The USK-0+420 indicates the place of borehole.

Segment-II occurs on 1400 meters of the survey site $(0+640-1+880 \mathrm{~km})$. On the investigation site 12 resistivity soundings, 12 seismic refraction measurements and one mechanical borehole, which is called KSK-1+068, were conducted. According to the underground structure estimated, the topsoil has resistivity values ranging from $13 \Omega \mathrm{m}$ to $45 \Omega \mathrm{m}$ corresponding to clay and sandy gravel respectively; the top soil thickness varies between $0.0 \mathrm{~m}$ and $5.00 \mathrm{~m}$. Layer 1's longitudinal and shear waves values range from 346 $\mathrm{m} / \mathrm{sn}$ to $550 \mathrm{~m} / \mathrm{s}$ and $152 \mathrm{~m} / \mathrm{sn}$ to $286 \mathrm{~m} / \mathrm{s}$, respectively. This layer can be affected by groundwater level. The weathered basement called Layer 2 has resistivity and thickness values varying between $2 \Omega \mathrm{m}$ and 31 $\Omega \mathrm{m}$ and 5.00-16.00 $\mathrm{m}$, respectively, under the first layer, respectively. It's primary and secondary wave velocities vary between $1261 \mathrm{~m} / \mathrm{sn}$ and $1943 \mathrm{~m} / \mathrm{s}$ and $415 \mathrm{~m} / \mathrm{sn}$ and $822 \mathrm{~m} / \mathrm{s}$. Its lithology is stiff clayey 
sand gravel. According to Eurocode-8, bearing capacitiy of this segment which Elasticitiy Modules lie between $1258 \mathrm{~kg} / \mathrm{cm}^{2}$ and $31069 \mathrm{~kg} / \mathrm{cm}^{2}$ and whose shear modules are $347-13482 \mathrm{~kg} / \mathrm{cm}^{2}$ are determined as loose, medium and stiff with increasing depth. This layer has Poisson Ratio values ranging from 0.04 to 0.44 . The well formation called KSK-1+068 is sandy clay with groundwater level at $4.20 \mathrm{~m}$.
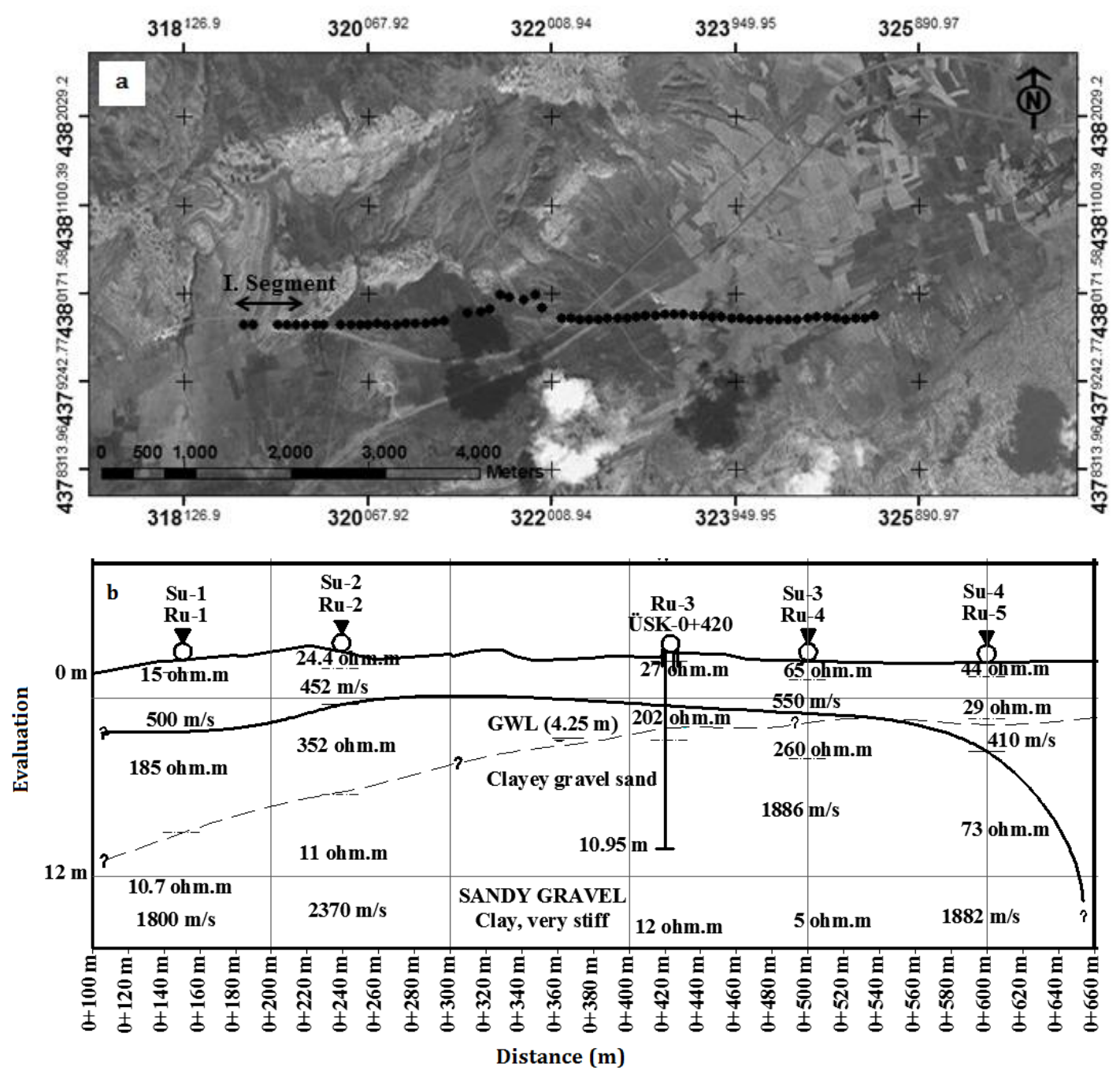

Figure 4. a) Map of route for Section-I b) Section-I drawn using measurements. Boreholes, seismic and electrical data shown in this section. Route of section can be seen on map above mentioned section. Points of geophysical measurement were marked as black point.

Segment-III lies between $1+880 \mathrm{~km}$ and $2+750 \mathrm{~km}$. It underwent six resistivity soundings, six seismic refraction measurements and two mechanical boreholes called ASK-1+195 and ASK-2+580. The length of section is $\mathbf{8 7 0}$ metres. It is specified as two layers according to seismic measurements. Groundwater levels varies between 5.80-6.30 meters. Seismic measurements were named from $\mathrm{Su}_{-} 17$ to Su_22. The first layer has resistivity values ranging from $3.2 \Omega \mathrm{m}$ to $20 \Omega \mathrm{m}$ corresponding to sandy hard clay. The topsoil's thickness varies between $0.0 \mathrm{~m}$ and $5.00 \mathrm{~m}$. Its values of longitudinal and shear waves range from $403 \mathrm{~m} / \mathrm{sn}$ to $601 \mathrm{~m} / \mathrm{s}$ and $168-287 \mathrm{~m} / \mathrm{s}$. The resistivity and thickness values of the weathered basement vary between 2.90-57 $\Omega \mathrm{m}$ and 5.00-16.00 $\mathrm{m}$ under Layer 1. The second layer has longitudinal waves value ranging from $1792 \mathrm{~m} / \mathrm{sn}$ to $2251 \mathrm{~m} / \mathrm{s}$. Shear wave velocities vary from $637 \mathrm{~m} / \mathrm{sn}$ to $901 \mathrm{~m} / \mathrm{sn}$. Layer 2 can be determined as sandstone formation. This segment which has elasticity modules as $1258-31069 \mathrm{~kg} / \mathrm{cm}^{2}$ and shear modules between $426 \mathrm{~kg} / \mathrm{cm}^{2}$ and $18470 \mathrm{~kg} / \mathrm{cm}^{2}$. According to Eurocode- 8 and Bowless soil classification for dynamic properties, this segment can be determined as "B" and "medium and stiff soil". Calculated Poisson values are ranging from 0.35 to 0.45 . It can be understood that layers are of porous structure. Sandy clay gravel formations can be seen during called ASK-1+195 and ASK-2+580 wells. Groundwater levels are 4.30-4.40. 
Segment-IV includes a stretch of rail cutting. The width of the cutting is 550 meters, lying, between $2+750$ $\mathrm{km}$ and 3+300 km (Figure 5). This section has five seismic refraction measurements and one well which is called YSK-2+900 for geotechnical properties. Two layers are determined in accordance with seismic investigation. The top soil thickness varies between $0.0 \mathrm{~m}$ and $5.00 \mathrm{~m}$ as claystone and gypsum. Their form is decayed rock. Thickness values of the weathered basement where is under top soil vary between 5.00-16.00 m. The second layer has longitudinal waves value ranging from $1696 \mathrm{~m} / \mathrm{sn}$ to $2251 \mathrm{~m} / \mathrm{s}$, shear waves values are $637-901 \mathrm{~m} / \mathrm{s}$. These can be determined as possible sandstone layers. Shear waves record could not be taken in this area. Mechanical borehole of lithology is gypsum - sandstone and siltstone. Seismic velocities of this section indicates soil with high bearing capacity. According to collected and calculated data, Section-IV can be seen in Figure 5a and Figure 5b.
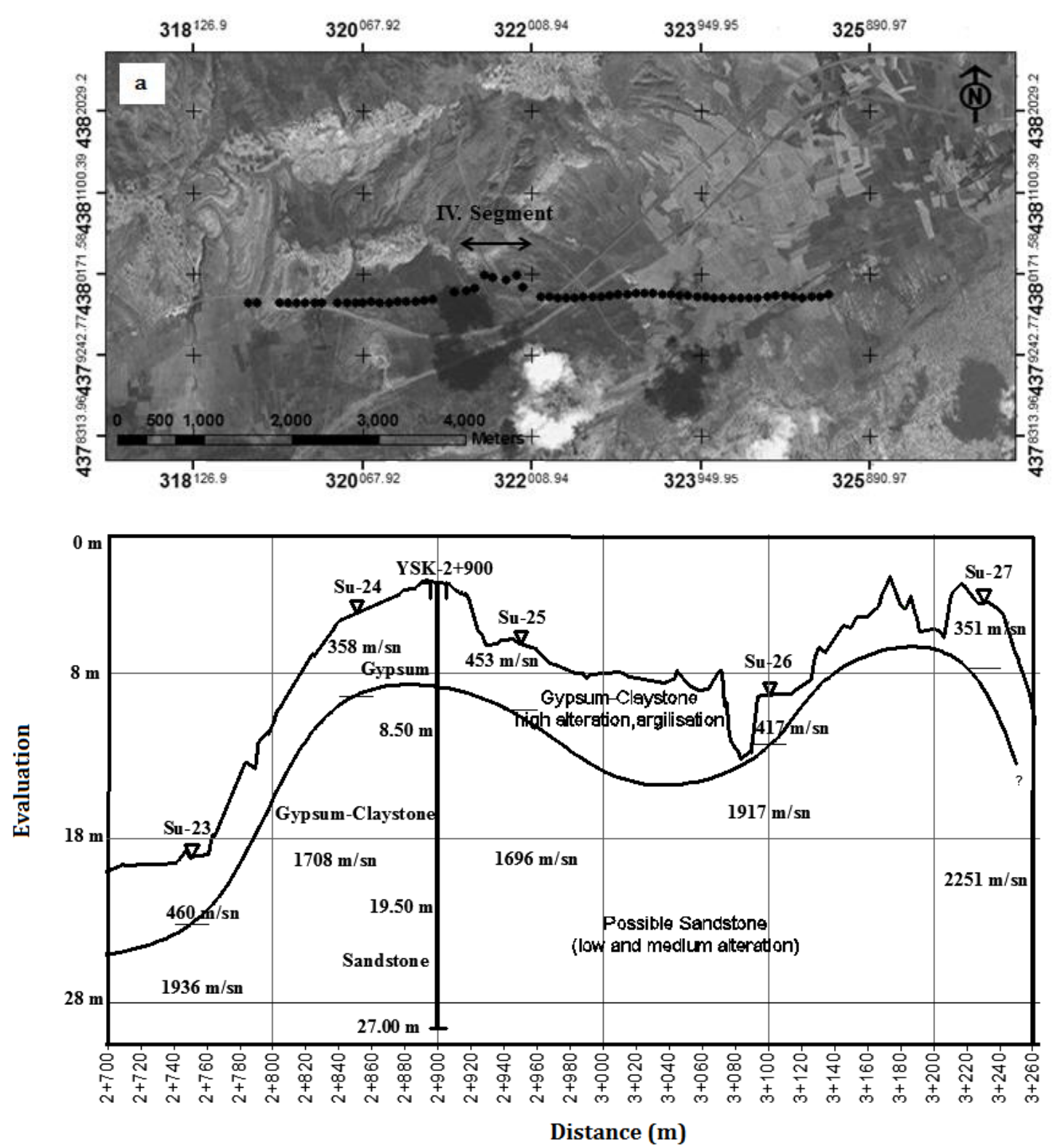

Figure 5. a) Map of route for Section-IV b) Section-IV drawn using measurements. Boreholes, seismic and electrical data shown in this section. Route of section can be seen on map above mentioned section. Points of geophysical measurement were marked as black point.

Segment-V lies between $3+300 \mathrm{~km}$ and $4+900 \mathrm{~km}$. The length of this section is $1600 \mathrm{~m}$. There were 15 resistivity soundings, 16 seismic refraction measurements, five mechanical boreholes which were called as SİSK_5, SİSK_8, SİSK_13, SİSK_14, ÜSK 4+635 and a test pit. The depth of the top layer, consisting of silty sand units, ranges from 0.00 to 5.00 meters values of $P$ and $S$ velocity vary between $236 \mathrm{~m} / \mathrm{sn}$ and $694 \mathrm{~m} / \mathrm{s}$, and $150-314 \mathrm{~m} / \mathrm{sn}$, respectively. Resistivity values range between $8 \Omega \mathrm{m}$ and $20 \Omega \mathrm{m}$. This layer is weathered. The weathered basement with the resistivity, P waves, $\mathrm{S}$ waves and thickness values vary between $3 \Omega \mathrm{m}$ and 40 


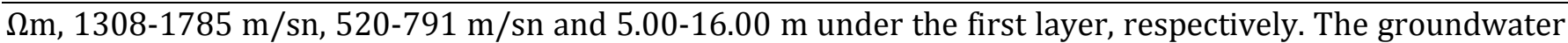
level varies between $3.00 \mathrm{~m}$ and $5.20 \mathrm{~m}$. According to Eurocode-8, the soil of the aligment ranges from B to C. According to Bowless soil classification for dynamic properties, this segment which has elasticity modules as $646-31906 \mathrm{~kg} / \mathrm{cm}^{2}$ and shear modules between $325-12314 \mathrm{~kg} / \mathrm{cm}^{2}$ can be determined as loose and stiff soil. Poisson Ratio ranges from 0.02 to 0.47 . Formations of SISK_5, SISK_8, SİSK_13, SİSK_14 and ÜSK-4+635 are clayey sand. Boreholes data and geophysical data match each others.

Segment-VI of track in this region lies between $4+900 \mathrm{~km}$ and $5+300 \mathrm{~km}$. Four resistivity soundings, four seismic refraction measurements and one well called ÜSK +520 were done on this section. The length of section is $400 \mathrm{~m}$ and two seismic layers were formed with seismic measurements. According to mechanical boreholes, ÜSK-5+250, between $\mathrm{Su}_{-} 44$ and $\mathrm{Su}_{-} 47$, the depth of the top layer is between $0.00 \mathrm{~m}$ and $5.00 \mathrm{~m}$, being silty sand gravel stiff units. P and S wave values vary between $506 \mathrm{~m} / \mathrm{sn}$ and $769 \mathrm{~m} / \mathrm{s}$, and 132-219 $\mathrm{m} / \mathrm{sn}$, respectively. Resistivity values range from $6 \Omega \mathrm{m}$ to $22 \Omega \mathrm{m}$. Resistivity, velocity of $P$ waves, velocity of $S$ waves and thickness values of weathered basement vary between 6-54 $\Omega \mathrm{m}, 1522-1692 \mathrm{~m} / \mathrm{sn}, 591-648$ $\mathrm{m} / \mathrm{sn}$ and 5.00-16.00 m, respectively, under the first layer. The type of this layer can be determined as stiff, sandy gravel units. Groundwater level is $5.30 \mathrm{~m}$. The soil of this section can be classified from B to C, especially as regards Eurocode-8. According to Bowless soil classification for dynamic properties, this segment which has elasticity modules as $748-28940 \mathrm{~kg} / \mathrm{cm}^{2}$ and shear modules between $528-11468 \mathrm{~kg} / \mathrm{cm}^{2}$ can be determined as medium and stiff soil. The Poisson Ratio changes 0.34-0.47. The lithology of the borehole called ÜSK $5+250$ is very stiff and suggests sandy gravel units. According to collected and calculated data, Section VI can be seen in Figure 6.

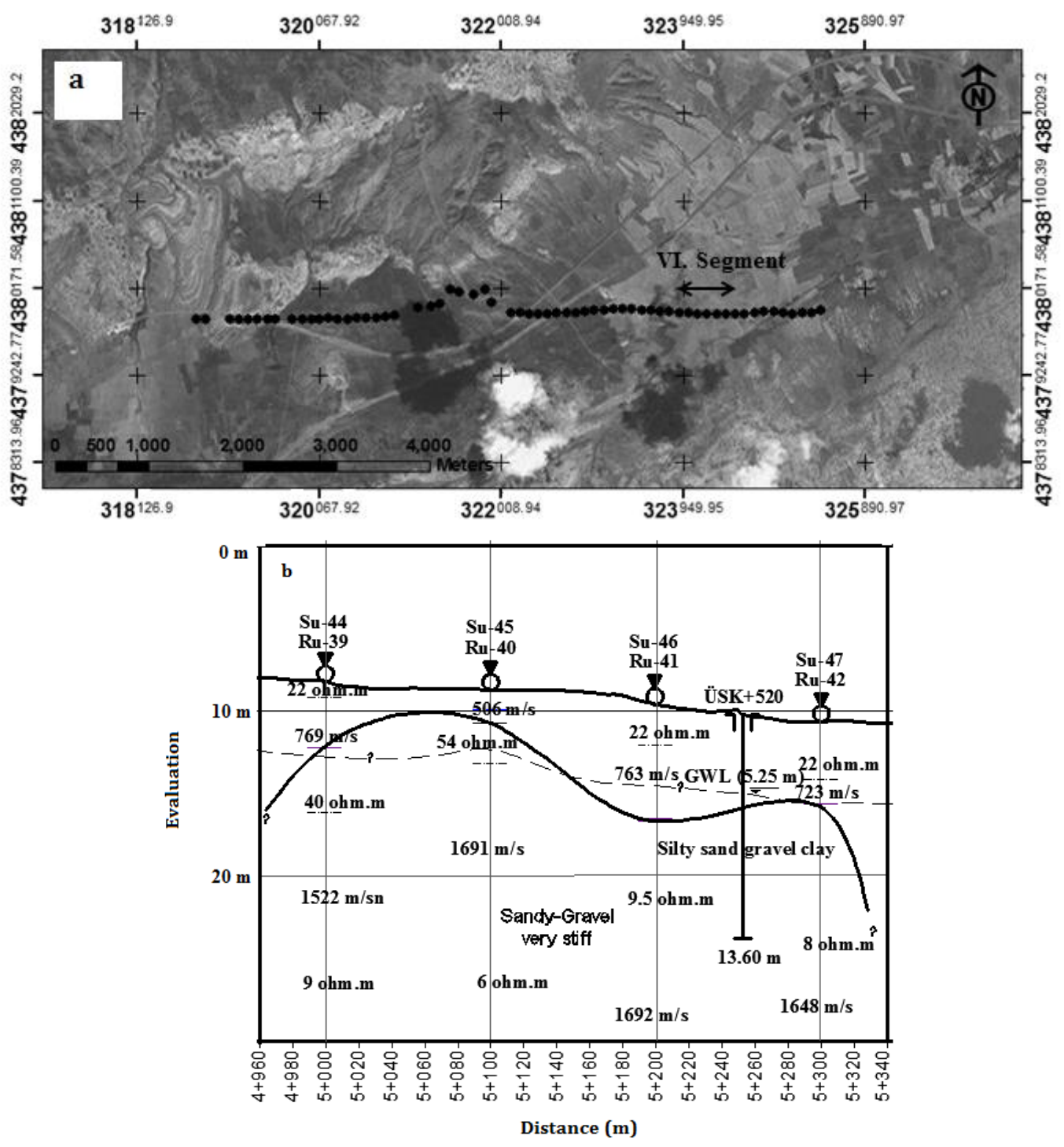

Figure 6. a) Map of route for Section-IV b) Section-VI drawn using measurements. Boreholes, seismic and electrical data shown in this section. Route of section can be seen on map above mentioned section. Points of geophysical measurement were marked as black point. 
Segment-VII includes $5+300 \mathrm{~km}-6+800 \mathrm{~km}$ of study area. 15 resistivity soundings, 15 seismic refraction measurements called Su_48-Su_62 and one mechanical borehole called ÜSK-6+305 and a test pit called AÇ$6+910$ were done on this field. The section length is 1400 meters. According to all seismic shot points, ÜSK$6+305$ of mechanical borehole, depth of top layer ranges between $0.00 \mathrm{~m}$ and $5.00 \mathrm{~m}$ as stiff silty sand gravel units. Values of P and S wave vary between $381 \mathrm{~m} / \mathrm{sn}$ and $794 \mathrm{~m} / \mathrm{s}$, and 164-321 m/sn, respectively. Resistivity values range from $14 \Omega \mathrm{m}$ to $27 \Omega \mathrm{m}$. Resistivity, P waves velocity, S waves velocity and thickness values vary between $4-70 \Omega \mathrm{m}, 1738-3001 \mathrm{~m} / \mathrm{sn}, 444-1532 \mathrm{~m} / \mathrm{sn}$ and 5.00-16.00 m, respectively, in the weathered basement under the first layer. The type of this layer could be determined as medium weathered rock. Soil of aligment can be classified B and C, according to Eurocode 8. Conglomera gaps can approximately be found within $5.00 \mathrm{~m}$ between the $\mathrm{Su} \_57$ and $\mathrm{Su}_{-} 60$ seismic shot points. This layer is waterlogged soil. According to the Bowless soil classification for dynamic properties, this segment which has elasticity modules as $826-14235 \mathrm{~kg} / \mathrm{cm}^{2}$ and shear modules between $290-53768 \mathrm{~kg} / \mathrm{cm}^{2}$ can be determined as medium and stiff soil. Poisson Ratio ranges from 0.23 to 0.47 . Formations of ÜSK- $6+305$ and AÇ+910 are silty sand and conglomera.

Bearing capacities which were calculated by use of laboratory tests and seismic methods can be seen in Table 4. Bearing capacitiy values calculated by using shear wave velocity range between $19.95 \mathrm{KPa}$ and 97 $\mathrm{KPa}$. According to USA soil classification standards, values of bearing capacities can be determined as D (stiff soil). Bearing capacity values calculated by using laboratory results range between $19.52 \mathrm{KPa}$ and $161 \mathrm{KPa}$. Stiffness of soil is medium hard with regards to the values of unconfined compressive test.

Table 4. Bearing capacities calculated by using laboratory tests and seismic methods

\begin{tabular}{|c|c|c|c|c|c|c|}
\hline $\begin{array}{l}\text { Name of } \\
\text { Borehole }\end{array}$ & $\begin{array}{l}\text { Groundwater } \\
\text { Level }\end{array}$ & $\begin{array}{c}\text { Soil } \\
\text { Classification }\end{array}$ & $\begin{array}{c}\mathrm{q}_{\text {soil }}(\text { Terzaghi}) \\
\mathrm{KPa}\end{array}$ & $\begin{array}{c}\mathrm{q}_{\text {soil }}(\mathrm{Broms}) \\
\mathrm{KPa}\end{array}$ & $\begin{array}{c}\mathrm{q}_{\text {soil }} \\
\left(\mathrm{V}_{\mathrm{p}}-\mathrm{V}_{\mathrm{s}}\right) \\
\mathrm{KPa}\end{array}$ & $\begin{array}{c}\mathrm{q}_{\text {soil }} \\
\text { (Triaxial } \\
\text { Compression Test) } \\
\mathrm{KPa}\end{array}$ \\
\hline USK_0+420 & 4.50 & SM & - & - & 78.0 & - \\
\hline KSK_1+068 & 4.30 & SM & - & - & 62.0 & - \\
\hline ASK_1+915 & 4.40 & CL & 46.26 & 46.05 & 58.5 & 128 \\
\hline ASK_2+580 & 4.30 & $\mathrm{SC}$ & - & - & 59.0 & - \\
\hline SİSK_5 & 10.0 & $\mathrm{CH}$ & - & - & 46.0 & - \\
\hline SISK_8 & 10.0 & CL & - & - & 97.0 & - \\
\hline SISK_13 & 2.40 & $\mathrm{CH}$ & 48.16 & 33.93 & 57.0 & 161 \\
\hline SISK_14 & 2.75 & $\mathrm{CH}$ & 19.95 & 19.92 & 51.0 & 151 \\
\hline USK_4+635 & 3.00 & $\mathrm{CH}$ & 35.30 & 34.55 & 45.0 & 144 \\
\hline USK_5+250 & 6.10 & $\mathrm{CH}$ & 52.00 & 52.00 & 79.0 & 132 \\
\hline USK_6+305 & 4.35 & SM & - & - & 77.0 & - \\
\hline
\end{tabular}

11 boreholes given with specific levels have minimum and maximum SPT (N) values of between 18 and 30 (see in Table 4). Bearing capacities calculated by using SPT blow counts (N) are between $223 \mathrm{KPa}$ and 438 $\mathrm{KPa}$ (see table 5). According to the Eurocode - 8 soil classification tables, which include SPT blow count (N) values. Calculated bearing capacities used all SPT blow counts (N). The soil can be classified as $\mathrm{C}$.

\section{Conclusion}

In this study, high speed track planned between the cities of Sivas and Erzincan was investigated with special regard to underground structure and bearing capacities of soils. Subsurface structure was determined by seismic velocities and resistivity distrubition calculated from seismic and electric resistivity methods on survey site. The total length of reviewed track was $6+800 \mathrm{~km}$. The maximum and minimum $\mathrm{P}$ wave and S wave velocities vary $273 \mathrm{~m} / \mathrm{s}-3001 \mathrm{~m} / \mathrm{s}, 132 \mathrm{~m} / \mathrm{s}-1532 \mathrm{~m} / \mathrm{sn}$. Elasticity and shear modules range from 646 to $53056 \mathrm{~kg} / \mathrm{cm}^{2}$ and from 290 to $53768 \mathrm{~kg} / \mathrm{cm}^{2}$. As a result of the investigation, it has been identified that the soil beneath the aligment examined has a layered structure. Layers were named according to depth as Layer 1 and Layer 2. The average thickness of layers are 0-5 m, and 5-16 m, respectively. According to calculated elastic parameters on track route, the bearing capacities of the soil depend on horizontal and vertical movements was determined as very weathered, weathered soils and stiff soils in some areas. Bearing capacitiy values calculated by using shear wave velocity range between 19.95 and 97 $\mathrm{KPa}$ Bearing capacitiy values calculated by using laboratory results range between 19.52 and $161 \mathrm{KPa}$. Bearing capacities calculated by using SPT blow counts (N) show values between 223 and $438 \mathrm{KPa}$. Bearing capacities calculated by using results of laboratory and seismic velocities are similar each other. 


\begin{tabular}{|c|c|c|c|c|c|c|}
\hline $\begin{array}{l}\text { Name of } \\
\text { Borehole }\end{array}$ & $\begin{array}{l}\text { Depth } \\
\text { (m) }\end{array}$ & $\begin{array}{c}\text { Soil } \\
\text { Classification }\end{array}$ & $\begin{array}{l}\text { SPT (N) } \\
\text { Blow } \\
\text { Counts } \\
\end{array}$ & $\begin{array}{c}q_{u l t} \\
\text { Terzaghi-Peck } \\
\mathrm{KPa}\end{array}$ & $\begin{array}{c}q_{u l t} \\
\text { Meyerhof (1974) } \\
\mathrm{KPa}\end{array}$ & $\begin{array}{c}q_{u l t} \\
\text { Average } \\
\mathrm{KPa} \\
\end{array}$ \\
\hline ÜSK_0420 & $\begin{array}{l}1.70 \\
3.20\end{array}$ & $\begin{array}{l}\text { SM } \\
\text { SM }\end{array}$ & $\begin{array}{l}26 \\
28\end{array}$ & 351.7 & 386.9 & 353 \\
\hline KSK_1068 & $\begin{array}{l}1.70 \\
3.20\end{array}$ & $\begin{array}{l}\text { SM } \\
\text { SM }\end{array}$ & $\begin{array}{l}21 \\
23\end{array}$ & 297.7 & 335.6 & 301 \\
\hline ASK_1915 & $\begin{array}{l}1.70 \\
3.20\end{array}$ & $\begin{array}{l}\text { CL } \\
\text { CL }\end{array}$ & $\begin{array}{l}24 \\
25\end{array}$ & 311.3 & 376.4 & 323 \\
\hline ASK_2580 & $\begin{array}{l}1.70 \\
3.20\end{array}$ & $\begin{array}{l}\mathrm{SC} \\
\mathrm{SC}\end{array}$ & $\begin{array}{l}18 \\
18\end{array}$ & 214.8 & 276.5 & 226 \\
\hline SISK_5 & $\begin{array}{l}1.70 \\
3.20\end{array}$ & $\begin{array}{l}\mathrm{CH} \\
\mathrm{CH}\end{array}$ & $\begin{array}{l}24 \\
30\end{array}$ & 469.8 & 414.9 & 438 \\
\hline SISK_8 & $\begin{array}{l}1.70 \\
3.20\end{array}$ & $\begin{array}{l}\text { CL } \\
\text { CL }\end{array}$ & $\begin{array}{l}20 \\
22\end{array}$ & 450.7 & 399.6 & 421 \\
\hline SISK_13 & $\begin{array}{l}1.70 \\
3.20\end{array}$ & $\begin{array}{l}\mathrm{CH} \\
\mathrm{CH}\end{array}$ & $\begin{array}{l}18 \\
20\end{array}$ & 221.9 & 291.9 & 236 \\
\hline SISK_14 & $\begin{array}{l}1.70 \\
3.20\end{array}$ & $\begin{array}{l}\mathrm{CH} \\
\mathrm{CH}\end{array}$ & $\begin{array}{l}21 \\
19\end{array}$ & 242.2 & 307.2 & 253 \\
\hline USK_4635 & $\begin{array}{l}1.70 \\
3.20\end{array}$ & $\begin{array}{l}\mathrm{CH} \\
\mathrm{CH}\end{array}$ & $\begin{array}{l}21 \\
18\end{array}$ & 233.8 & 299.6 & 248 \\
\hline USK_5250 & $\begin{array}{l}1.70 \\
3.20\end{array}$ & $\begin{array}{l}\mathrm{CH} \\
\mathrm{CH}\end{array}$ & $\begin{array}{l}23 \\
20\end{array}$ & 300.7 & 314.5 & 296 \\
\hline USK_6305 & $\begin{array}{l}1.70 \\
3.20\end{array}$ & $\begin{array}{l}\text { SM } \\
\text { SM }\end{array}$ & $\begin{array}{l}13 \\
19\end{array}$ & 210.3 & 272.8 & 223 \\
\hline
\end{tabular}

Bearing capacity results which is calculated by SPT is different from other results because The SPT is affected by several factors, such as overburden stress, rod length, and equipment type and so the $\mathrm{N}$ value measured in the field should be corrected to N60 or (N1)60, which is computed by multiplying the N value by the correction factors of overburden stress, energy ratio, borehole diameter, sampling method, and rod length. Ultimate bearing capacity results which is found by seismic measurements is dynamic parameters. For this reason, results of bearing capacity can be lower values. Liquefaction problems can be seen on the survey site because of existing groundwater. The bearing capasities of examined weak zones should be strengthened and groundwater should be removed from the media.

\section{Acknowledgements}

In this study, the data collected from survey site were used within the scope of the Sivas -Erzincan high speed railway project. We are thankful to Ministry of Transport, Maritime Affairs and Communications of Republic of TURKEY for giving us permission to use their data.

\section{References}

Adiat, K.A.N., Adelusi, A.O., Ayuk, M.A., 2009. Relevance of geophysics in road failures investigation in a typical basement complex of Southwestern Nigeria. The Pacific Journal of Science and Technology 10(1): 528-539.

Basokur, A.T., 1999. Automated 1-D interpretation of resistivity soundings by simultaneous use of the direct and iterative methods, Geophysical Prospecting 47(2), 149-177.

Broms, B., 1964. The lateral resistance of piles in cohesive soils. Journal of the Soil Mechanics and Foundations Divisions. ASCE 90(SM2): 27-63.

Bowles, J.E., 1988. Foundatıon analyses and design. 4th Edition, McGraw - Hill International Editions, Civil Engineering Series, New York, USA.

Bowles, J.E., 1996. Foundation analysis and design. 5th edition, McGraw - Hill International Editions, Civil Engineering Series. Press, New York, USA.

Das, B.M., 2009. Soil mechanics: Laboratory manual, Oxford University Press Inc. Newyork, USA. 299p.

Gardner, G.H.F., Gardner, L.W., Gregory, A.R., 1974. Formation velocity and density the diagnostic basics for stratigraphic traps. Geophysics 39(6): 770-780.

Imai, T., Yoshimura, M., 1976. The relation of mechanical properties of soils to $\mathrm{P}$ and S wave velocities for soil ground in Japan. Urana Research Institue, OYO Corporation, OYO Technical Note 07, Japan. 15p

Jongmans, D., 1992. The application of seismic methods for dynamic characterization of soils. Bulletin of International Association of Engineering Geology 46(1): 63-69. 
Keçeli A., 1990. The determination of the dynamic permissible bearing capacity and Settlement by means of the seismic method. Jeofizik 4(2): 83-92. [in Turkish]

Keçeli, A., 2010. Determination of soil bearing capacity and consolidation using seismic method. Uygulamalı Yer Bilimleri Dergisi 9(1): 23-41. [in Turkish]

Kramer S.L., 1996. Geotechnical Earthquake Engineering. Prentice Hall Inc. New Jersey, USA. 653p.

Kulhawy, F.H., Mayne, P.W., 1990. Manual of estimating soil properties for foundation design. Research Project 1493-6, Geotechnical. Engineering Group, Cornell University, Ithaca, New York, USA

Kurtuluș, C., 2000. Examination of bearing capacity from seismic velocities. Uygulamalı Yer Bilimleri Dergisi 6: 51-59. [in Turkish]

Lippincott, T., Cardimona, S., Anderson, N. Hickman, S., Newton, T., 2000. Geophysical site characterization in support of highway expansion Project. Symposium on the Application of Geophysics to Engineering and Environmental Problems 2000. Environment and Engineering Geophysical Society. pp. 587-596.

Meyerhof, G.G., 1956. Penetration tests and bearing capacity of cohesionless soils. Journal of the Soil Mechanics and Foundations Division, ASCE, 82 (SM1): 1-16.

Meyerhof, G.G., 1965. Shallow foundations. Journal of the Soil Mechanics and Foundations Division, ASCE 91(SM2): 21-31.

Meyerhof, G.G., 1974. Ultimate bearing capacity of footings on sand layer overlaying clay. Canadian Geotechnical Journal 11(2): 223-229.

Moore, R.W., 1952. Geophysical methods adapted to highway engineering problems. Geophysics 17(3): 505-530.

Nelson, R.G., Haigh, J.H., 1990. Geophysical investigation of in lateritic terrain. In: Geotechnical and Environmental Geophysics, Volume 2-Environmental and Groundwater. Ward, S.H. (Ed.)., Society of Exploration Geophysicists , Tulsa, USA. pp.133-154.

Olorunfemi, M.O., Idoringie, A.I., Coker, A.T., Babadiya, G.E., 2004. On the application of the electrical resistivity method in foundation failure investigation - A case study. Global Journal of Geological Sciences 2(1): 139-151.

Prandtl, L., 1921. Hauptaufsätze: Über die Eindringungsfestigkeit (Härte) plastischer Baustoffe und die Festigkeit von Schneiden. Zeitschrift fur Angewandte Mathematik und Mechanik 1(1): 15-20.

Phillips, D.E., Han, D.H., Zoback, M.D., 1989. Empirical relationships among seismic velocity, effective pressure, porosity, and clay content in sandstone. Geophysics 54(1): 82-89.

Pyrak-Nolte, J., Roy, S., Mullenbach, B.L., 1996, Interface waves propagated along a fracture. Journal of Applied Geophysics 35(2-3): 79-87.

Schulze, W.E., 1943. Grundbau Deutsche Forschungsgesellschaft für Bodenmechanik. 7th edition. B.G. Taubner Publishers, Leipzig, Germany.

Sully, J.P., Campanella, R.G., 1995. Evaluation of in situ anisotropy from crosshole and downhole shear wave velocities measurements. Géotechnique 45(2): 267-282.

Sharma, P.V., 1997, Environmental and Engineering Geophysics, Cambridge University Press, Cambridge, UK. 468p.

Sheehan, J.R., Doll, W.E., Mandell, W.A., 2005. An evaluation of methods and available software for seismic refraction tomography analysis. Journal of Environmental and Engineering Geophysics 10(1): 21-34.

Tatham, R.H., 1982. Vp/Vs and lithology. Geophysics 47(3): 336-344.

Telford, W. M., Geldart, L. P., Sheriff, R. E. 1990. Applied geophysics, 2nd edition, Cambridge University Press, Cambridge, 792p.

Terzaghi, K., 1943. Theoretical Soil Mechanics. John Wiley \& Sons. Inc. New York , USA. 503p.

Terzaghi, K., Peck, R.B., 1948. Soil Mechanics in Engineering Practice, Wiley, New York, USA.

Terzaghi, K., Peck, R.B., Mesri, G., 1967. Soil Mechanics in Engineering Practice. John Wiley \& Sons. Inc. NY, USA. 529p.

Tezcan, S., Keceli, A., Ozdemir, Z., 2006. Allowable bearing capacity of shallow foundations based on shear wave velocity. Geotechnical and Geological Engineering 24(1): 203-218.

Tezcan, S.S., Ozdemir, Z., Keceli, A., 2009. Seismic technique to determine the allowable bearing pressure for shallow foundations in soils and rocks. Acta Geophysica 57(2): 400-412.

Turker, E., 2004, Computation of ground bearing capacity from shear wave velocity. In: Continuum Models and Discrete Systems. Bergman, D.J., Inan, E. (Eds.). NATO Science Series (Series II: Mathematics, Physics and Chemistry), vol 158. Springer, Dordrecht. pp.173-180.

Ulugergerli, E.U., Uyanık, O., 2007. Statistical correlations between seismic wave velocities and SPT blow counts and the relative density of soils. Journal of Testing and Evaluation 35(2): 187-191.

Uyanık 0., 1999. Expolaration of velocities and sliding resistance on rocks. 52. Türkiye Jeoloji Kurultayı Bildiriler Kitabı, 10-12 Mayıs, Ankara, Turkey. pp. 63-70. [in Turkish]

Uyanık, O., Türker, A.E., 2007, Interpretation and Geotechnical Properties of Potential Landslide in Fethiye-Eşen II HEPP Power Collection and Plant Area. Süleyman Demirel Üniversitesi, Fen Bilimleri Enstitüsü Dergisi 11(1): 84-90. [in Turkish]

Uyanık, O., Ulugergerli, E.U., 2008, Quality control of compacted grounds using seismic velocities. Near Surface Geophysics 6(5): 299-306.

Willkens, R., Simmons, G., Caruso, L., 1984. The ratio Vp/Vs as a discriminant of composition for siliceous limestones. Geophysics 49(11): 1850-1860. 